\title{
Reseña del libro Interpelaciones. Indicios y fracturas en textos latinoamericanos, de Luz Rodriguez Carranza (2019) Serie Zona
} de Crítica. Eduvin-Editorial Universitaria de Villa María. Villa María, Córdoba. 396 páginas. ISBN: 9789876995757

\section{Laura Alassia}

FHUC-UNL (Facultad de Humanidades y Ciencias.

Universidad Nacional del Litoral, Argentina)

En Interpelaciones. Indicios y fracturas en textos latinoamericanos se reúnen una serie de ensayos de Luz Rodriguez Carranza sobre textos latinoamericanos. Conforma el catálogo de Zona de Crítica, una de las más importantes colecciones de libros dedicados a la literatura latinoamericana dirigida por la Profesora e Investigadora Roxana Patińo. En Zona de Crítica están, además, los libros monográficos de los más importantes críticos literarios de nuestro país y el continente, y particularmente la mencionada colección se enfoca en la producción de la crítica literaria sobre la literatura latinoamericana.

Los ensayos que Carranza selecciona para este libro comparten dos características y así lo señala la autora: «Por un lado, hay en ellos prácticas que no parecen responder a ninguna de las exigencias manifiestas que las preceden. Por otra parte, esas acciones van acompañadas siempre por imágenes que impiden toda explicación causal, todo relato. Las imágenes son indicios -en el doble sentido de la palabra, huella y señalización- de situaciones y emociones que no están a la vista ni son expresadas, pero que interpelan de manera extrańa».

El itinerario que nos propone la lectura es apasionante: desde el archivo de las revistas culturales de los años 60-70, en los estereotipos del Borges de los años '30, pasando por algunas novelas duchampianas de César Aira en los '90, para concluir en obras recientes como 
Spam, de Rafael Spregelburd y Birdman, de Alejandro González Iñarrirtu. Cada capítulo detecta rupturas inexplicables y resultados inesperados. Aparecen así sujetos fieles a sus propias interpelaciones y a sus propios actos, y se abren espacios que no podrán volver a cerrarse.

«Archivo» es el primer capítulo. Si archivo es sinónimo de clasificado, olvidado y arrumbado en depósitos, de viejo para decirlo más rotundamente, es cuando la juventud se hace lugar en él cuando puede volver a interpelar. Esta es la clara apuesta del primer capítulo. El primer ensayo que lo inaugura se titula «Sísifo y los mapas». Carranza puntualiza lo inédito del texto en español y que abarca publicaciones de toda Hispanoamérica durante una década: la de los relatos del «boom» y la del «posboom» de la novela latinoamericana de los años '6o, escritos en los '70 y los '80 que clasificaron las revistas como discursos unívocos, según los textos editoriales, sus fuentes de financiación o las declaraciones actuales de antiguos colaboradores. Los discursos son múltiples, por un lado se entrelazan o polemizan entre sí, a veces hasta dentro de un mismo artículo. Por otro lado, las agendas y temarios continentales obligatorios son traducidos a problemáticas locales. Hay un enjambre de interpelaciones y las más interesantes para la autora son las que aparecen simultáneamente en revistas que nada parece relacionar entre sí: voces y discursos silenciados, enemigos comunes que no adquirieron derecho de archivo pero que fueron paradójicamente más fuertes que todas las ideologías y lealtades.

Los otros dos apartados del capítulo son ejemplos de esas apariciones que sacuden las causas y los efectos. El primero, «los demonios inútiles» es uno de los artículos fetiches de la autora porque toca de manera muy sensible su historia personal. Es un análisis de dos revistas argentinas paradigmáticas de los 60-70, Primera Plana, semanario progresista y liberal, y Los libros, la revista teórica de izquierda más importante de los primeros años de los '7o en su primera etapa, dirigida por Hector Schmucler. Ambas revistas defienden el valor absoluto de la época, la eficiencia, que para Primera Plana es la modernización y para Los libros, el compromiso.

«Imágenes», el segundo capítulo, se abre con un ensayo sobre reflexiones de Jorge Luis Borges que destaca sus relaciones con otras de la primera mitad de siglo xx: las de Bergson, las de las investigaciones sobre el movimiento de Marey, las de Warburg sobre las fórmulas patéticas y las que se preocupan por la incipiente cultura de masas, desde Le Bon a Walter Benjamin. También surgen voces como la de los filólogos preocupados por las fórmulas orales de la cultura popular: Parry, un romanista como Curtius, o un hispanista como Menendez Pidal. 
Si para Bergson hay un punto de encuentro entre la imagen, que es espacio y materia, y la memoria, que es tiempo $\mathrm{y}$ virtualidad, Borges muestra que entre ambas hay siempre un agujero negro que nos interpela, sobre todo en aquellos casos donde como las fórmulas y los géneros, parecen irrevocablemente selladas entre sí. Luz Rodriguez Carranza se interesa particularmente en los del joven escritor vanguardista preocupado por la cultura de masas y los géneros populares y analizando dos ejemplos de imágenes diagramáticas que interpelaban a su manera desviada la creciente dominación fascista de la cultura de los años $30 \mathrm{del}$ siglo pasado: los géneros epidíctico y biográfico en la columna «libros y autores extranjeros» de la revista El hogar (1936-39) y los héroes caricaturescos y vulgares de la Revista multicolor de los sábados, suplemento de Crónica que dirigieron Borges y Ulises Petit de Murat entre 1933 y 1934.

«Indicios» tiene el claro propósito de mostrar y señalar, contempla aquellas que Carranza concibe como "novelas del cambio de siglo en las que hay una transmisión directa de la experiencia y del presente». En «El objeto Duchamp» el interés coincide con un nuevo realismo en literatura a principios del siglo XXI que se propone lograr equivalencias de la realidad, no de representarla usando estereotipos como si fuera la primera vez, haciéndolos nombrar el presente.
Son así interpretaciones ready made a la experiencia, descritas en una genealogía desde las novelas de La Onda en México en los '60 a Los pichiciegos de Fogwill en I982, y a obras mexicanas argentinas y mexicanas de la primera década del 2000. Junto a Contreras (2018) Carranza afirma que las obras de Aira son los mejores ejemplos de estos nuevos realismos. En «Usos de la utopía» analiza a partir del relato de Rafael Hytlodeo en la obra de Tomas Moro y del clonador de estilo en El congreso de literatura de Aira, la función de los señuelos y los duplicados en el deseo. "Los mundos sutiles» sugiere a partir de La fuente y de Como me reí que el lenguaje mismo puede construir una experiencia en lugar de dejarla fuera. Es el lenguaje de los thesauri del renacimiento el de los alquimistas y herboristas, el de Rubén Darío y de las palabras-indicio que como los deícticos y los nombres propios son performativas.

El último capítulo, «Sujetos» está divido en dos partes. El título de la primera «Perfiles» alude al bosquejo de las identidades. Autorretratos describe un género que como el ornitorrinco de Gould no es ni un antecesor ni un sucesor de otras especies sino otra especie diferente, un género que coexiste con la autobiografía y con otras variantes de los relatos de sí, como las autoficciones. Es el género de las Confesiones de San Agustín y de los Ensayos de Montaigne, de Jerome 
Cerdan o de Michel Leiris: la yuxtaposición de todas las voces y discursos que han interpelado al escritor quien en un ejercicio de sicastenia exhibe el artificio que es su única razón de ser.

«Caricaturas» refiere a un género que no produce cadáveres sino zombies. Exagerando los rasgos prominentes de los personajes, sin embargo, delata una identidad siniestra que pasa desapercibida en otros retratos. En la forma extrema se ridiculizan la personalidad, la identidad y todas las certezas. Es poco frecuente que un escritor dibuje, en una novela casi paradójicamente autobiográfica una caricatura de sí mismo no solo como personaje sino también como narrador. Carlos Fuentes, caricaturista y frecuentemente caricaturizado lo hace en Diana o la cazadora solitaria, aunque nunca se sabrá como en el caso de Pándaro, si fue voluntaria o involuntariamente.

"Actos» anuda el lazo con la propuesta inicial del libro, mostrando rupturas definitivas con todas las interpelaciones comunitarias o ideológicas y también con todas las inmunizaciones identitarias. Aunque no haya síntesis posible entre las interpelaciones que tironean simultáneamente y el conflicto permanezca candente entre ellas los mundos cambian definitivamente después del salto al vacío de los personajes y no hay regreso.

"Amparos» describe la búsqueda desesperada de protección de los presos en una cárcel cubana a quienes ya no les bastan ni los discursos revolucionarios de afuera ni las leyes no escritas de adentro. En ese mundo no hay carceleros: los presos se disciplinan a sí mismos y a los demás según leyes no escritas que obedecen a una ideología racista y machista y a una comunidad en la que la protección y la lealtad mutua entre compañeros de celda son los lazos sociales y garantías de sobrevivencia. Los protagonistas viven cotidianamente la contradicción entre ambos sistemas éticos y sus propios deseos y se resisten pasivamente a través de las lágrimas y el melodrama o activamente suicidándose o como el narrador liberándose de la deuda del munus con la traición.

La expresión «I did» se encuentra literal en tres obras de diferentes géneros: Simone novela del puertorriqueño Eduardo Lalo, Spam ópera hablada del argentino Rafael Spregelburd y Birdman, película del mexicano Gonzalez Iñárrirtu. En los tres casos los sujetos confrontan la responsabilidad de sus propios actos. Las decisiones desafían cualquier valor o reconocimiento. Los protagonistas viven rodeados de desechos y algunos de esos restos se convierten en mensajes que provienen de ellos mismos. Aunque saben que la interpelación es un simulacro, actúan jugándose el todo por el todo porque señala deseos y emociones auténticamente suyos. No hay finales, 
hay resultados acontecimientos que no fueron planificados ni buscados pero se descubren después de la ruptura como en el epitafio de Raymond Carver que es el epígrafe de Birdman:

¿y conseguiste lo que querías de esta vida, a pesar de todo?

I did.

Y ¿qué querías?

Nombrarme amado, sentirme amado sobre la tierra. 